DOI: $10.25140 / 2411-5363-2019-4(18)-18-21$

Олександр Размишляєв, Віталій Іванов, Марина Агєєва

\title{
ФОРМУВАННЯ ЗОНИ ПРОПЛАВЛЕННЯ ПРИ НУЛЬОВІЙ ШВИДКОСТІ ЕЛЕКТРОДУГОВОГО НАПЛАВЛЕННЯ ДРОТЯНИМ ЕЛЕКТРОДОМ ПІД ФЛЮСОМ
}

\begin{abstract}
Актуальність теми дослідження. Дуже важливим є питання формоутворення зварювальної ванни при нульовій швидкості наплавлення. Це пов'язано з тим, щзо процес наплавлення доиільно починати при нульовій швидкості переміщення дуги, щзоб встановився розмір шва (валика) на початку виконання наплавлення.

Постановка проблеми. При формоутворенні зварювальної ванни при нульовій швидкості наплавлення буде виключена початкова ділянка шва, коли прочес є несталим у тепловому сенсі. При цьому доцільно визначити час, протягом якого основний метал буде проплавлений до розмірів, щьо відповідають технічним вимогам, тобто при швидкості, встановленій для иъвого технологічного процесу.

Аналіз останніх досліджень $і$ публікацій. Для процесу дугового наплавлення зазвичай використовують теорію теплових процесів, розроблену М. М. Рикаліним як для рухомої дуги зі швидкістю наплавлення, так і для нерухомої, коли швидкість наплавлення дорівнює нулю.

Виділення недосліджених частин загальної проблеми. У літературі немає даних, присвячених питанню формоутворення зварювальної ванни при нульовій швидкості дугового наплавлення під флюсом.

Постановка завдання (цілей статті). Аналіз можливості застосування відомої теорії розповсюдження тепла при зварюванні для визначення розмірів точки, щзо формується при нульовій швидкості дугового наплавлення.

Виклад основного матеріалу. На основі теорії розповсюдження тепла при зварюванні М. М. Рикаліна визначені зміни температури в часі залежно від радіуса точки, щзо формується. Співставленням розрахункових $і$ експериментальних даних встановлено їх неспівпадання.

Висновки відповідно до статmі. Визначено, щзо для встановлення розмірів зони проплавлення при дуговому наплавленні дротяним електродом під флюсом із нульовою швидкістю треба враховувати не тільки дифузійну (кондуктивну), а й конвективну складову перенесення тепла, яка виникає внаслідок руху метала у ванні.

Ключові слова: дугове наплавлення; дифузійний $і$ конвективний механізми перенесення тепла; електромагнітні сили Лорениа.

Рис.: 2. Бібл.: 2.
\end{abstract}

Актуальність теми дослідження. Дуже важливим є питання формоутворення зварювальної ванни при нульовій швидкості наплавлення. Це пов’язано з тим, що процес наплавлення доцільно починати при нульовій швидкості переміщення дуги, щоб встановився розмір шва (валика) на початку виконання наплавлення.

Постановка проблеми. При формоутворенні зварювальної ванни при нульовій швидкості наплавлення буде виключена початкова ділянка шва, коли процес є несталим у тепловому сенсі. При цьому доцільно визначити час, протягом якого основний метал буде проплавлений до розмірів, що відповідають технічним вимогам, тобто при швидкості, встановленій для цього технологічного процесу.

Аналіз останніх досліджень і публікацій. Для процесу дугового наплавлення зазвичай використовують теорію теплових процесів, розроблену М. М. Рикаліним [1] як для рухомої дуги зі швидкістю наплавлення, так і для нерухомої, коли швидкість наплавлення дорівнює нулю [1;2].

Виділення недосліджених частин загальної проблеми. У літературі немає даних, присвячених питанню формоутворення зварювальної ванни при нульовій швидкості дугового наплавлення дротом під флюсом.

Виклад основного матеріалу. $\mathcal{C}$ рішення для постійно діючого точкового джерела, розташованого на поверхні напівнескінченного тіла при нульовій швидкості наплавлення. У цьому випадку не враховується діаметр електрода, а використовується ефективна теплова потужність дуги $\left(q_{u}\right)$ і теплофізичні константи основного матеріалу. Приріст температури $\Delta T$ в часі від безперервно діючого теплового джерела визначається за формулою $[1 ; 2]$ :

(с) Размишляєв О. Д., Іванов В. П., Агєєва М. В., 2019 
TECHNICAL SCIENCES AND TECHNOLOGIES

$$
\Delta T=\frac{q_{u}}{2 \pi \lambda R}(1-\Phi(u)),
$$

де $q_{u}=\eta_{u} I_{H} U_{\partial}$ - ефективна теплова потужність зварювальної дуги, Вт;

$I_{H}$ - струм наплавлення, А;

$U_{\partial}$ - напруга на дузі, В;

$\eta_{u}$ - ефективний ККД процесу нагрівання основного металу дугою;

$\lambda$ - коефіцієнт теплопровідності, Вт/м·К;

$R$ - радіус-вектор від джерела тепла до розглянутої точки, м;

$a$ - коефіцієнт температуропровідності, $\mathrm{M}^{2} / \mathrm{c}$;

$\Phi(u)$ - функція інтеграла ймовірності від аргументу $u, u=\frac{R}{\sqrt{4 a t}}$;

$t$ - час, с.

Були виконані розрахунки для випадку наплавлення дротом Св-08А діаметром 4 мм під шаром флюсу АН-60 постійним струмом зворотної полярності з такими параметрами режиму: $I_{H}=650 \mathrm{~A} ; U_{\partial}=32 \mathrm{~B} ; v_{H}=0 \mathrm{~m} / \mathrm{c}$. Значення констант і теплофізичних коефіцієнтів: $\eta_{u}=0,9 ; \lambda=40 \mathrm{BT} / \mathrm{M} \cdot \mathrm{K} ; a=0,08 \cdot 10^{-4} \mathrm{~m}^{2} / \mathrm{c}$.

Для порівняння результатів розрахунку з реальними значеннями були проведені експериментальні наплавлення з технологічними параметрами, які були наведені вище, на пластини 3 маловуглецевої сталі товщиною 20 мм. Після наплавлення виготовляли макрошліфи, за якими визначали параметри зони проплавлення. Отримані залежності геометричних параметрів наведені на рис. 1, 2 спільно з розрахунковими даними.

Дані розрахунків (рис. 1) показують, що для точок, що лежать на колі $R=$ const $(R=2 ; 5 ; 7 ; 10$ мм) з плином часу температура точок неухильно зростає, що не відповідає реальним результатам, отриманим експериментальним шляхом, які свідчать про припинення росту глибини проплавлення і просування ізотерми плавлення $T_{n л}=1773 \mathrm{~K}$ $\left(1500^{\circ} \mathrm{C}\right)$ вглиб основного металу.

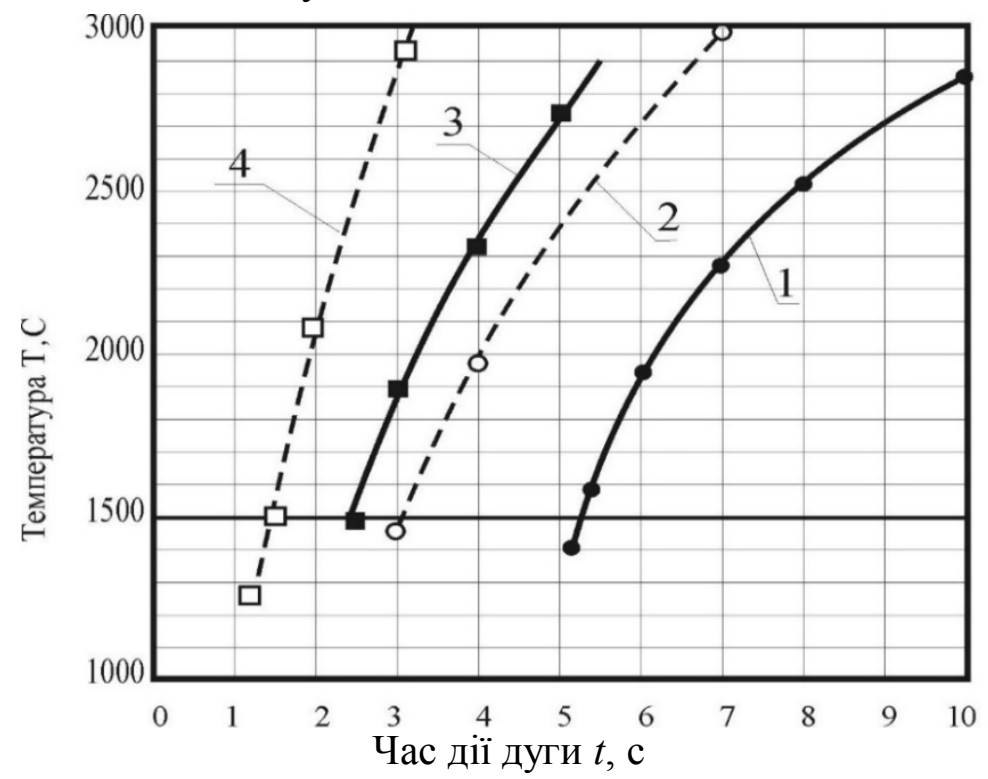

Рис. 1. Зміна температури в часі залежно від радіуса:

1, 2, 3, 4-відповідно, $R=10,7,5,2$ мм

Просування фронту плавлення, тобто відстані від точки введення тепла в будь-якому напрямку відбувається в часі практично лінійно (рис. 2, крива 5), що не відповідає експериментальним даним (рис. 2, криві 2,4 ). Також виявилося, що характер зміни розрахункового значення $R(t)$ набагато різкіший, ніж за даними експерименту, i, навпаки, експериментальні значення глибини проплавлення $\left(h_{n p},\right)$ )значно більші, ніж розрахункові. 


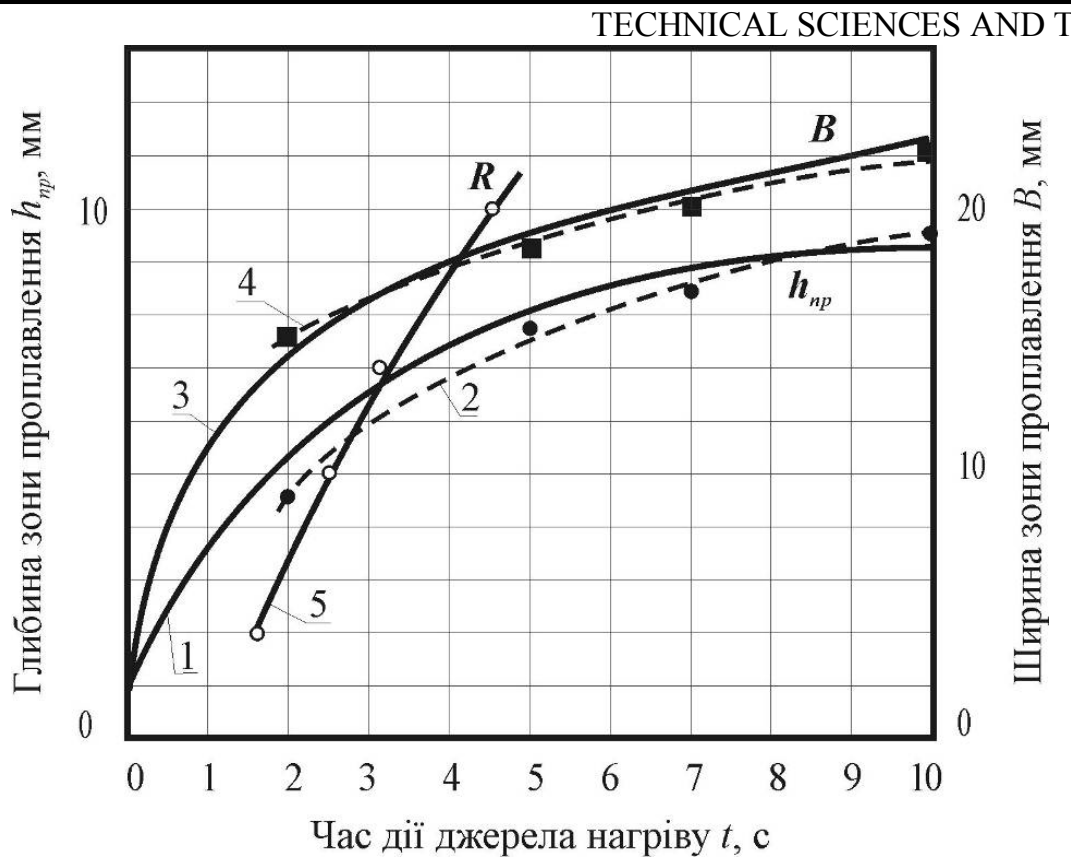

Рис. 2. Динаміка зростання розмірів зони проплавлення (ізотерми $T_{n л}=1773 \mathrm{~K}$ ) залежно від часу дії нерухомого джерела нагрівання:

1, 2 - глибина проплавлення; 3, 4- иирина проплавлення; 2, 4-експериментальні дані; 5 - результати розрахунку за формулою (1)

Основна відмінність розрахункових даних від експериментальних значень полягає в тому, що приріст температури в кожній точці зони плавлення з плином часу продовжує зростати, хоч і обмежується значенням виразу $\frac{q_{u}}{2 \pi \lambda R}$, наближаючись до нього при $t \rightarrow \infty$, досягаючи декілька хвилин.

Крім того, зміна в часі розрахункових контурів зони проплавлення не відповідає контурам, отриманим експериментальним шляхом, причому останні мають більш складну форму. Це пов'язано з наступним. При порушенні дуги в результаті плавлення основного металу в ньому утворюється лунка (початковий кратер), куди починає надходити розплавлений електродний метал, надаючи додаткове тепловкладення у ванну. Потім, на твердих стінках лунки, що утворюється, зростає прошарок рідкого металу, який негативно впливає на умови теплопередачі від дуги в основний метал. У період зростання зони проплавлення рідкий метал врівноважується тиском дуги й розташовується рівномірно на дні та стінках кратера. У міру збільшення обсягу рідкого металу зростає і його гідростатичний тиск, витісняючи дугу до верхньої частини кратера, тим самим ще більше уповільнюючи зростання глибини проплавлення аж до його зупинки. У міру зростання об'єму ванни в центрі зони проплавлення має місце характерне поглиблення, що виникає завдяки осьовому потоку електродного металу, а також наявності розвинених потоків рідкого металу, що призводить до відхилення контуру остаточної ізотерми плавлення від гладкої кривої другого порядку. При розрахунках також не врахований рух рідкого металу під дією електромагнітних сил Лоренца. Потоки рідкого металу в зварювальній ванні змінюють умови теплоперенесення в ній, тобто слід враховувати конвективний механізм теплоперенесення при формуванні розмірів ванни.

Висновки відповідно до статті. Розрахунками встановлено, що для розмірів зони проплавлення при дуговому наплавленні дротяним електродом під флюсом із нульовою швидкістю необхідно враховувати не тільки дифузійну (кондуктивну), а й конвективну складову перенесення тепла, яка виникає внаслідок руху метала у ванні. 


\section{TECHNICAL SCIENCES AND TECHNOLOGIES \\ Список використаних джерел}

1. Фролов В. В. Теория сварочных процессов: учебник для вузов по специальности Оборудование и технология сварочного производства. Москва: Высшая школа, 1988. 559 с.

2. Karkhin V. A. Thermal Processes in Welding. Singapore: Springer. 2019. 492 p.

\section{References}

1. Razmyshlyaev, A. D., Mironova, M. V. (2009). Magnitnoe upravlenie formirovaniem valikov $i$ shvov pri dugovoi naplavke i svarke [Magnetic control of formation of beads and welds in arc surfacing and welding]. Mariupol: PGTU [in Russian].

2. Karkhin V. A. (2019). Thermal Processes in Welding. Singapore: Springer.

UDC 621.791 .75

\section{Aleksandr Razmyshlyaev, Vitaliy Ivanov, Marina Ahieieva FORMATION OF PENETRATION AREA AT ZERO VELOCITY OF SUBMERGED ELECTRIC ARC SURFACING WITH WIRE ELECTRODE}

Urgency of the research. Very important is the question of the welding bath formation at zero surfacing velocity. This is due to the fact that the surfacing process is advisable to start at zero velocity of the arc to establish the size of the weld (beam) at the surfacing beginning.

Target setting. When forming a welding bath at zero surfacing velocity, the initial weld section will be excluded when the process is unstable in the thermal sense. In this case, it is advisable to determine the time during which the base metal will be smelted to the size corresponding to the specifications, that is, at the velocity set for this technological process.

Actual scientific researches and issues analysis. The theory of thermal processes, developed by N.N. Rykalin, is usually used for the arc surfacing process both for a moving arc with a surfacing velocity and for a stationary one when the surfacing velocity is zero.

Uninvestigated parts of general matters defining. There is no data in the literature concerning the welding bath formation at zero velocity of submerged arc surfacing.

The research objective. Analysis of the possibility of applying the heat spread theory in welding to determine the size of the forming point at zero velocity of arc surfacing.

The statement of basic materials. Based on the theory of heat spread during welding by N.N. Rykalin defined changes in temperature over time depending on the radius of the forming point. Matching of the calculated and experimental data established their mismatch.

Conclusions. It has been stated that in order to establish the dimensions of the penetration zone during submerged arc surfacing with a wire electrode at zero velocity, not only the diffusion (conductive), but also the convective component of heat transfer, which occurs as a result of the metal movement in the bath, should be taken into account.

Keywords: arc surfacing; diffuse and convective heat transfer mechanisms; electromagnetic Lorentz forces.

Fig.: 2. References: 2.

Размишлясв Олександр Денисович - доктор технічних наук, професор, професор кафедри автоматизації та механізації зварювального виробництва, ДВНЗ «Приазовський державний технічний університет» (вул. Університетська, 7, м. Маріуполь, 87555, Україна).

Razmyshlyaev Aleksandr - Doctor in Technical science, Professor, Professor of automation and mechanization of welding production department, State Higher Educational Institution «Pryazovskyi state technical university» (7 Universitetska Str, 87555 Mariupol, Ukraine).

E-mail: razmyshlyaev@rambler.ru

ORCID: https://orcid.org/0000-0001-6616-7717

SCOPUS Author ID: 6602501672

Іванов Віталій Петрович - кандидат технічних наук, доцент, доцент кафедри автоматизації ті механізації зварювального виробництва, ДВНЗ «Приазовський державний технічний університет» (вул. Університетська, 7, м. Маріуполь, 87555, Україна).

Ivanov Vitaliy - PhD in Technical science, Associate Professor, Associate Professor of automation and mechanization of welding production department, State Higher Educational Institution «Pryazovskyi state technical university» (7 Universitetska Str, 87555 Mariupol, Ukraine).

E-mail: ivital64@ukr.net

ORCID: http://orcid.org/0000-0003-3339-7633

SCOPUS Author ID: 56496036500

Агєєва Марина Володимирівна - кандидат технічних наук, доцент, доцент кафедри обладнання і технологій зварювального виробництва, Донбаська державна машинобудівна академія (вул. Академічна, 72, м. Краматорськ, 84300 Україна).

Ahieieva Marina - PhD in Technical science, Associate Professor, Associate Professor of equipment and technology of welding production department, Donbass state engineering academy (72 Akademicheska Str., 84300 Kramatorsk, Ukraine).

E-mail: maryna ah@ukr.net

ORCID: https://orcid.org/0000-0001-8275-6781

SCOPUS Author ID: 57197921565

Размишляєв О., Іванов В., Агєєва М. Формування зони проплавлення при нульовій швидкості електродугового наплавлення дротяним електродом під флюсом. Технічні науки та технологіï. 2019. № 4 (18). С. 18-21. 